\title{
Fusarium graminearum in a Papilloma Virus Infected Friesian Bull in Vom, Nigeria: Case Report
}

\author{
*1FAGBAMILA I.O., ${ }^{2}$ MESEKO C.A., ${ }^{2}$ ADEDEJI J.A., 'NGULUKUN S.S., ${ }^{3}$ AKALUSI Y., 'DALIS, J.S., \\ ${ }^{4}$ AKANBI B.O., ${ }^{5}$ ZWANDOR N.J., ${ }^{5}$ OKPARA J., ${ }^{1}$ ANKELI P.I., ${ }^{2}$ ASALA, O.O., ${ }^{1}$ TAAMA L., and ${ }^{1}$ MUHAMMAD, M.
}

${ }^{1}$ Bacterial Research Division. ${ }^{2}$ Viral Research Division. ${ }^{3}$ Bacterial Vaccine Production Division. ${ }^{4}$ Central Diagnostic Division. ${ }^{5}$ Livestock Investigation Division. National Vet Research Institute, Vom. *Correspondence: dridowu4u@yahoo.com, Telephone: +2348033669580

\begin{abstract}
INTRODUCTION
Importation of exotic cattle to improve the yield and productivity of the local 'White Fulani' breed of cattle has been on the rise in Nigeria. The problem most farmers faces with the Friesian has always been the adaptation to the weather and endemic disease conditions in Nigeria. Fungal infections represent an important complication for immunosuppressed animals and are associated with high morbidity and mortality (De Pauw and Meunier, 1999). Fusarium is one of the most important fungal genera, which includes many species that are pathogenic to plants and responsible for a broad range of diseases while others are highly mycotoxigenic (Viquez et al., 1996) and some cause opportunistic infections in humans and in farm animals.

Fusarium graminearum (Gibberella zeae) is an important pathogen of commercial crops such as wheat, maize, and rice. Infection with F. graminearum causes yield losses in grains and degrades their nutritive, physical and chemical qualities, resulting in their being used for animal feed rather than for human consumption (Charmley et al., 1994). A contaminated crop can be salvaged by feeding it to livestock or poultry, but further losses may be incurred due to the negative effects of mycotoxins on animal performance. Potent toxins such as the estrogenic toxin zearalenone (F-2) have been reported by Vesonder and Hesseltine, (1980) but the most common mycotoxins produced by F. graminearum are deoxynivalenol (DON, also known as vomitoxin), 15-acetyldeoxynivalenol, and nivalenol belonging to a group of compounds known as trichothecenes (Homdork et al., 2000; Council for Agricultural Science and Technology, CAST, 2003). These mycotoxins are known to diminish feed consumption in domestic livestock, especially swine (CAST 2003). Because of their apparent tolerance for higher levels of dietary DON, Fusarium-infested grains are often fed to cattle or sheep as opportunity feeds. This may be due to little or insufficient information describing the pathogenesis and the ability of this plant pathogen to survive as they move through the gastrointestinal tract of cattle or on a compromised skin (Kedar and Gemerlyn, 2008).
\end{abstract}

KEY WORDS: Cattle, Papillomatosis, Fusarium graminearum, Isolation.

\section{CASE REPORT}

A Friesian bull was introduced into a herd that had a history of Papillomatosis. The bull was observed to have heavy tick infestation and crusty lesions on the skin suspected to be Dermatophilosis upon introduction to the herd. The bull was quarantined and topically treated with Lamstreptocide ${ }^{\circledR}$ (Red earth, Oleic acid and Terminalia Spp) sprayed with acaricide (Amytrax, 250mg/ml) and Oxytetracycline L.A $20 \mathrm{mg} / \mathrm{kg}$ was administered IM. There was remission of lesions after 3 months and the bull was released into the herd. However, one year later, lesions were noticed again on the skin. Appetite, temperature and pulse rate were within normal range but there was lameness and loss of weight. Grossly, the bull's skin appeared reddish with an ulcerated center which was covered by a black leathery scar. Discrete, multiple to diffuse, solitary, coalescing and necrotizing lesions were observed on the trunk and the extremities. Irregularly raised, pendunculated cauliflower-like growths (warts) were obvious. These lesions were distributed on the head, neck face, ears, mandibular regions, legs, scrotum, hump, shoulders, dorsum and the lateral abdomen. Some were found on the posterior hind limbs and perineum (Fig 1).

\section{Management plan}

Skin scrapings were collected in sterile containers and submitted for Bacteriological, Virological and Parasitological examinations. The samples were negative for ectoparasites (ticks, mites, lice) and Dermatophilus congolensis but positive for Papilloma virus. The specimen was also taken to Mycology Laboratory where it was inoculated onto a universal bottle containing Sabouraud's Dextrose Agar (SDA). The bottle was loosely covered and incubated at room temperature in a humidified chamber for 
seven days. The isolate was characterized based on morphology of thallus and microscopic appearance of hyphae, macroconidia and microconidia as described by Murray et al. (2005). Briefly, a drop of lactophenol cotton blue stain was placed on a clean glass slide. A portion of mycelium was transferred into the lactophenol cotton blue stain and teased with a dissecting needle. Cover slip was placed on the preparation and examined under the microscope for identification.

\section{RESULTS AND DISCUSSION}

Macroscopically, hyaline mold that produced white cottony colonies at the early stage and a rose-red diffusible pigment as they mature suggestive of Fusarium graminearum was isolated. This is as described by Segal et al.
(1998) (Plate 1). Microscopically, elongated multicelled, sickle macroconidia typical of Fusarium graminearum was observed (Plate 2). Histopathologically, the skin showed ortokeratotic hyperkeratosis with increased granular cell and keratohyaline granules, hyperplastic non cornified epidermis with formation of rete ridges (Figures 2 and 3 ) and downward 'pegs' projecting into the dermis. In addition, acanthotic spinous cells, fibrosis and mononuclear cellular infiltration- (fibropapilloma) were observed.

The disease state of animals determines the severity of infection with fusarium spp. Information regarding the host defense mechanism against Fusarium spp is scarce. Mycotoxins produced by

Figure1: AFriesian bull showing papilloma lesion where Fusarium graminearum was isolated.

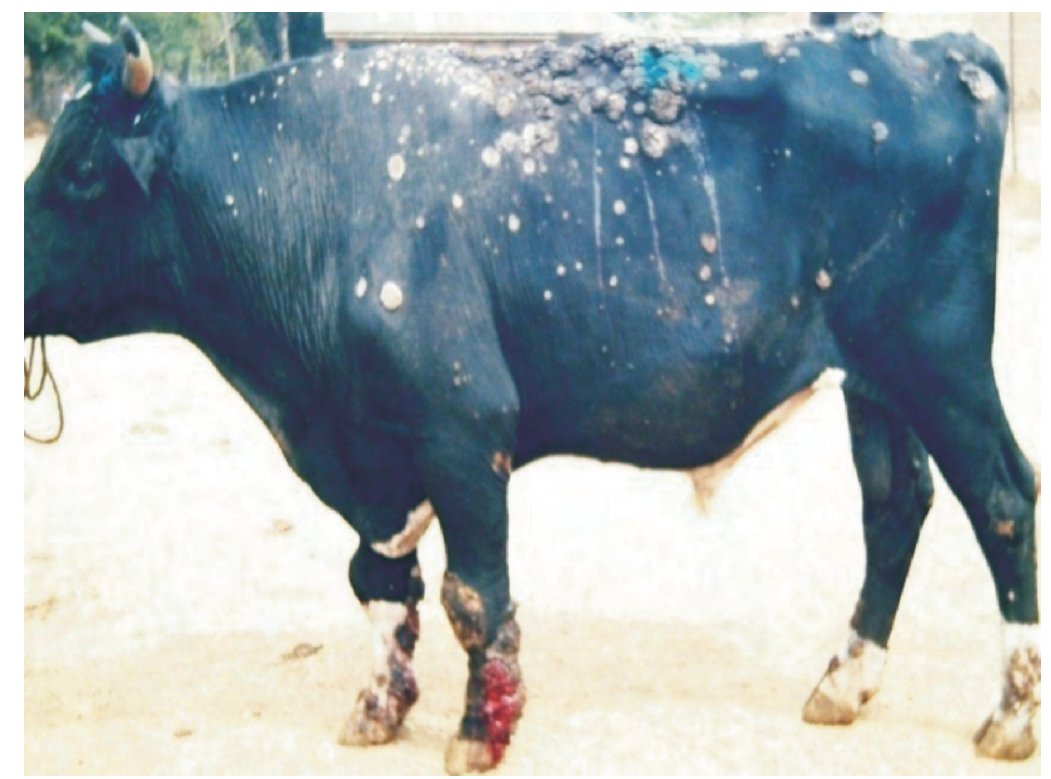

Figure 2: Hyperplasia of stratum spinosum and Rete ridge

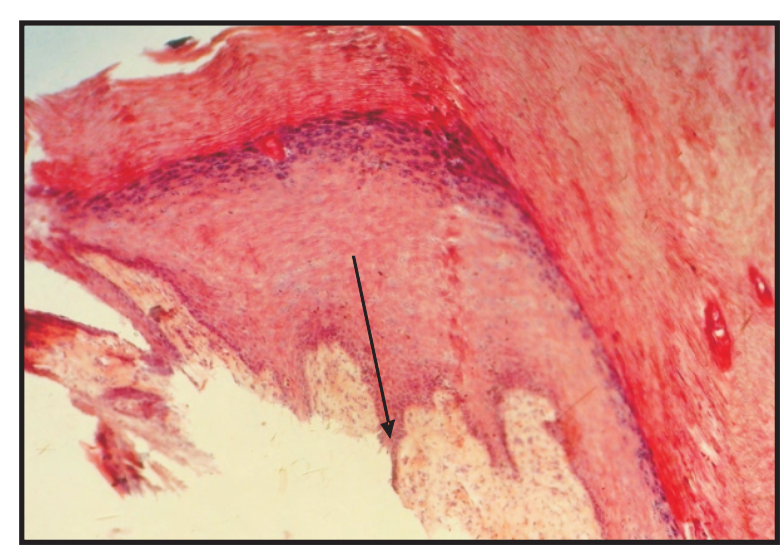

Figure 3: Intercellular Spongiosis

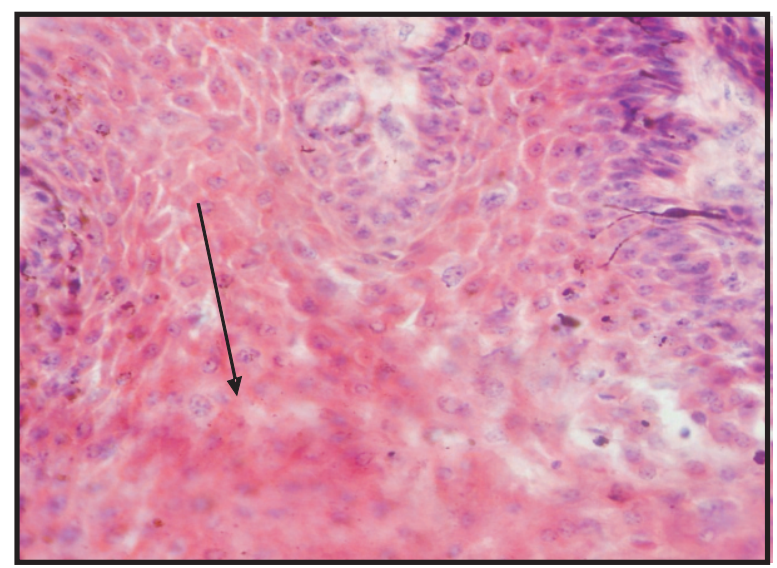


Plate 1: Macroscopic appearance of Fusarium graminearum on plate

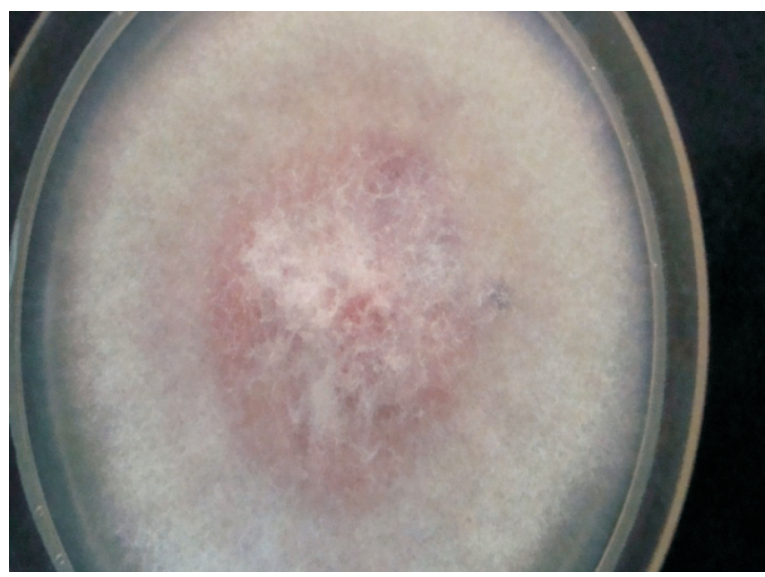

Fusarium species have been shown to suppress cellular and humoral immunity and cause tissue breakdown (Nelson et al., 1994). Fusarium graminearium is a pathological agent capable of infecting vital organs of the body such as the liver, skin, lungs and spleen. It induces leukocytosis in addition to possessing the ability to digest elastin and collagen (Kedar and Gemerlyn, 2008). The enzymes collagenase and elastase produced by $F$. graminearum may enhance its damaging effect on tissues. The characteristic lesions seen in this disease condition like drying, sloughing and ulceration of the skin and injuries of the extremities could be possibly related to the damaging effect of these enzymes. Fusariosis in immunocompromised populations is typically invasive and disseminating, unlike infections in the normal host (Nucci and Anaissie, 2002). Respiratory fusariosis is acquired by inhalation of airborne fusarial conidia. The skin also serves as a portal of entry of infection following skin breakdown due to trauma in normal hosts (Nucci and Anaissie, 2002), and the development of cellulitis, which may remain localized or lead to disseminated infection in immunocompromised animals (Nucci et al., 2003).

Infections by Fusarium graminearium can be superficial or systemic in otherwise healthy animals. Such infections are rare and tend to respond well to therapy. By contrast, disseminated fusariosis affecting immunocompromised hosts, especially animals with severe and prolonged neutropenia can be fatal.
Plate 2: Macrocornidia and microcornidia of Fusarium graminearum

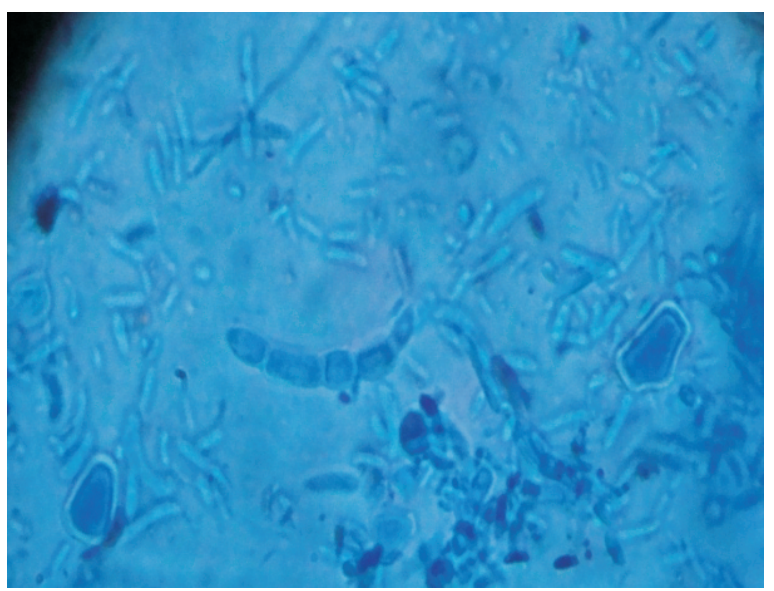

A successful outcome is determined largely by the degree and persistence of immunosuppression and the extent of infection, with a $100 \%$ death rate for persistently neutropenic animals with disseminated disease. The possible detoxification of trichothecene by rumen microorganisms has made farmers whose cereals are infected with $F$. graminearum to feed it to ruminants. Where good hygiene is not practiced this organism may gain access through a compromised skin. It was concluded that infection with papilloma virus could have compromised the skin and provided an enabling condition for infection by Fusarium graminearum which further compounded the severity of the papilloma infection. This is the first time to our knowledge that fusariosis has been confirmed in cattle in Nigeria. The bull died before treatment could be instituted.

\section{REFERENCE}

CHARMLEY, L.L., ROSENBERG, A., AND TRENHOLM, H.L. (1994): Factors responsible for economic losses due to Fusarium mycotoxin contaminants of grains, foods, and feedstuffs. Pp.s 471-486 in J.D. Miller and H.L. Trenholm (eds.) Mycotoxins in Grains: Compounds Other Than Aflatoxins. Eagan Press, St. Paul, MN

COUNCIL FOR AGRICULTURAL SCIENCE AND TECHNOLOGY, CAST (2003). Mycotoxins: Risks in Plant, Animal and Human Systems. CAST, Ames, Iowa, USA. 199.

DE PAUW, B.E AND MEUNIER, F (1999): The challenge of invasive fungal infection. Chemotherapy, 45 (1):1-14.

HOMDORK $_{2}$ S., FEHRMANN, H AND BECK R (2000): Influence of different storage conditions on the mycotoxin production and quality of Fusarium- 
infected wheat grain. Journal of Phytopathology, 148: 7-15.

KEDAR B. K AND GEMERLYN G. G (2008): Assessment of the Pathogenicity Property of Fusarium Graminearum 1 in Balb/c Mice. http://www.articlesbase.com/medicinearticles/assessment-of-the-pathogenicityproperty-of-fusarium-graminearum-1-in-balbcmice-316287.html\#ixzz0nnoicbzb. Accessed on 13th may 2010

MURRAY, P.R., ROSENTHAL, K.S AND PFALLER, M. A (2005): Superficial and cutaneous mycosis. In: Medical Microbiology, $5^{\text {th }}$ edition page 745-751

NELSON, P.E., DIGNANI, M.C. AND. ANAISSIE, E J (1994): Taxonomy, biology, and clinical aspects of Fusarium species. Clinical Microbiology Reviews, 7:479-504.

NUCCI, M AND ANAISSIE, E (2002): Cutaneous Infection by Fusarium Species in Healthy and Immunocompromised Hosts: Implications for Diagnosis and Management. Chicago journal of Clinical infectious Disease, 35:909-920.
NUCCI, M., ANAISSIE, E.J., QUEIROZ-TELLES, F., MARTINS, C.A., TRABASSO, P., SOLZA, C., MANGINI, C., SIMOES, B.P., COLOMBO, A.L., VAZ, J., LEVY, C.E., COSTA, S., MOREIRA, V.A., OLIVEIRA, J.S., PARAGUAY, N., DUBOC, G., VOLTARELLI, J.C., MAIOLINO, A., PASQUINI, R. AND SOUZA, C.A (2003): Outcome predictors of 84 patients with hematologic malignancies and Fusarium infection. Cancer, 98:315-319.

SEGAL, B. H., WALSH, T. J., LIU, J. M., WILSON, J. D. AND KWON-CHUNG, K. J (1998): Invasive infection with Fusarium chlamydosporum in a patient with aplastic anemia. Journal of Clinical Microbiology, 36:1772-1776.

VESONDER, R.F AND HESSELTINE, C.W (1980): Vomitoxin: natural occurrence on cereal grains and significance as a refusal and emetic factor to swine. Process Biochemistry, 16:12-15

VIQUEZ, O.M., CASTELL-PEREZ, M.E AND SHELBY, R.A (1996): Occurrence of fumonisin B, in maize growing Costa Rica. Journal of Agricultural and Food Chemistry, 44:2789-2799. 